\title{
Aplikasi Pelacakan Rumah Sakit Berbasis Android Dengan Algoritma Pencarian
}

\author{
Ryan Cipta Permata ${ }^{\mathrm{a} 1}$, Herman Kuswanto ${ }^{\mathrm{a} 2}$, Muhamad Ryansyaha ${ }^{\mathrm{a} 3}$, Muhammad Sony Maulana $^{\mathrm{b} 1}$ \\ a STMIK Nusamandiri Jakarta, Jln Jatiwaringin Raya No.02 Rt.08 Rw.013 Kelurahan Cipinang Melayu \\ Kecamatan Makasar Jakarta Timur 13620 \\ ${ }^{b}$ Program Studi Sistem Informasi Kampus Kota Pontianak, Universitas Bina Sarana Informatika \\ Jl. Abdurahman Saleh No.18 \\ ${ }^{1}$ ryanciptapermata@gmail.com \\ 2herman.hko@nusamandiri.ac.id \\ 3muhamad.mur@nusamandiri.ac.id \\ ${ }^{4}$ muhammad.sony.momebsi.ac.id
}

\begin{abstract}
Abstrak
Suatu kota yang mempunyai cukup banyak rumah sakit. Rumah sakit merupakan salah satu pelayanan kesehatan untuk masyarakat melakukan pemeriksaan secara rutin ataupun untuk pemeriksaan. Tetapi tidak semua masyarakat tidak mengetahui lokasi atau keberadaan rumah sakit terdekat. Kekurangan tentang informasi lokasi rumah sakit di kota memberi peluang penulis untuk membuat aplikasi pelacakan rumah sakit secara cepat. oleh sebab itu untuk efisiensi pelacakan rumah sakit, penulis membuat aplikasi pencarian rumah sakit ,yang dikembangkan untuk piranti telpon cerdas berbasis Android menggunakan Visual Code Studio dan menggunakan metode Waterfall. Aplikasi yang sudah dibuat telah dapat memenuhi kebutuhan untuk melakukan proses pelacakan rumah sakit dari piranti telpon cerdas dengan memberikan posisi yang cukup akurat, Aplikasi pelacakan rumah sakit ini dapat menampilkan rute perjalan ke rumah sakit dari dengan posisi pengguna berserta jaraknya sekarang ini dalam bentuk peta, Hasil pengujian yang sudah dilakukan adalah bahwa fungsifungsi di aplikasi pelacakan rumah sakit ini dapat berjalan dengan benar dan sesuai dengan kriteria pembuatan.
\end{abstract}

Kata kunci: Rumah sakit, Visual Code Studio, Android

\section{Android Based Hospital Tracking Application}

\section{With a Search Algorithm}

\begin{abstract}
A city that has many hospitals. The hospital is one of the health services for the community to carry out routine checks or for check-ups. But not all people do not know the location or whereabouts of the nearest hospital. The lack of information on the location of hospitals in the city allowed the author to create a hospital tracking application quickly. Therefore, for the efficiency of hospital tracking, the authors created a hospital search application, which was developed for Android-based smartphones using Visual Code Studio and using the Waterfall method. The application that has been made has been able to fulfill the need to carry out the hospital tracking process from a smartphone by providing a fairly accurate position. This hospital tracking application can display the route to the hospital from the user's position along with the current distance in the form of a map. what has been done is that the functions in this hospital tracking application can run correctly and according to the manufacturing criteria.
\end{abstract}

Keywords: Hospital, Visual Code Studio, Android.

\section{Pendahuluan}

Setiap salah satu kota yang mempunyai cukup banyak rumah sakit. Rumah sakit merupakan salah satu pelayanan kesehatan untuk masyarakat melakukan pemeriksaan secara rutin ataupun untuk pemeriksaan. Tetapi tidak semua masyarakat tidak mengetahui lokasi atau keberadaan rumah sakit. Kekurangan tentang informasi lokasi rumah sakit di kota-kota memberi peluang penulis untuk membuat aplikasi pelacakan rumah sakit cepat. Saat ini dengan kemajuan dan perkembangan jaman maka 
informasi bisa didapatkan dengan mudah dan cepat kapanpun dan dimanapun.

Mengingat pentingnya pelayanan kesehatan bagi setiap penduduk menjadikan rumah sakit mempunyai peranan yang penting dalam menjawab kebutuhan masyarakat akan pelayanan kesehatan. Dalam Keputusan Menteri Kesehatan Republik Indonesia No. 340 tahun 2010, dikatakan bahwa rumah sakit merupakan sebuah institusi pelayanan kesehatan yang menyelenggarakan pelayanan kesehatan perorangan secara paripurna yang menyediakan pelayanan rawat inap, rawat jalan dan gawat darurat [1].

Saat ini teknologi begitu pesat berkembang. Pertukaran informasi dan begitu cepat seakan tidak ada jarak serta segala sesuatu terasa dekat. Begitu pesat perkembangan teknologi, munculah teknologi piranti telpon cerdas dengan OS (Operating System) android. Android adalah satu perkembangan teknologi, munculah teknologi piranti telpon cerdas yang paling populer, dikarenakan penjualanya dengan range harga yang terkangkau dan terdapat banyak aplikasi yang disediakan pemilik android yaitu Google.

Android merupakan sistem operasi untuk telepon seluler yang berbasis Linux. Android menyediakan platform terbuka bagi para pengembang untuk menciptakan aplikasi mereka sendiri untuk digunakan oleh bermacam piranti telpon cerdas bergerak. Android umum digunakan di perkembangan teknologi, munculah teknologi piranti telpon cerdas [2].

Android adalah sebuah sistem operasi untuk perangkat mobile berbasis Linux yang mencakup sistem operasi, middleware dan aplikasi[3].

Pesatnya perkembangan teknologi informasi saat ini berdampak pada gaya hidup masing-masing individu, hal ini dapat dilihat dari semakin banyaknya pengguna perkembangan teknologi, munculah teknologi piranti, mulai dari piranti telpon cerdas berbasis android hingga berbasis IOS. Beberapa kelebihan dari piranti telpon cerdas adalah untuk melakukan berbagai kegiatan seperti browsing, chatting, sosial media, email, game online, dan online shopping. Berawal dari perkembangan teknologi ini kegiatan-kegiatan yang sebelumnya hanya bisa dilakukan di perangkat keras komputer dapat dilakukan dengan mudah dan cepat pada piranti telpon cerdas [4].

Kemajuan teknologi saat ini terutama dibidang aplikasi berbasis android sudah tidak dapat diabaikan lagi. Android merupakan platform perangkat lunak yang digunakan untuk piranti bergerak (mobile device), yang didukung oleh google OS, android menggunakan modifikasi dari karenel linux yang dapat didistribusikan secara terbuka (open source) sehingga menarik minat bagi pengembang software untuk memodifikasi dan membuat aplikasi sendiri [5].

Google Maps adalah sebuah layanan yang diberikan secara gratis oleh Google. Layanan ini berisi peta dunia yang bisa kita manfaatkan untuk melihat atau menampilkan suatu daerah menggunakan suatu browser. Pengguna Google Maps bisa dengan mudah menampilkan peta di halaman web atau blog dengan menggunakan Google Maps API [6].
Pelacakan lokasi rumah sakit merupakan salah satu pelacakan yang diperlukan oleh masyarakat, dengan adanya aplikasi pelacakan rumah sakit berbasis android, maka akan memudahkan para masyarakat untuk mendapatkan rute perjalanan menuju lokasi tersebut, dengan menampilkan peta yang dilengkapi rute menuju lokasi tersebut [7].

\section{Metodologi Penelitian}

Pencarian merupakan proses yang fundamental dalam pengolahan data. Sequential Searching merupakan algoritma pencarian beruntun yang prosesnya membandingkan setiap elemen satu persatu secara beruntun, mulai dari elemen pertama sampai elemen yang di cari di temukan atau seluruh elemen sudah di periksa [8].

Algoritma pencarian rumah sakit dengan metode Algorithma pencarian (searching algoritma) adalah algoritma yang menerima sebuah argumen kunci dan dengan langkah-langkah tertentu akan mencari rekaman dengan kunci tersebut [9].

Rumus pencarian yaitu :

1.Jika data tidak terurut (data acak), maka pencarian akan dilanjutkan ke data selanjutnya.

2. Jika data terurut secara menaik (ascending), maka pencarian hanya akan dilanjutkan ke data selanjutnya yang berada di sebelah kanan data yang sedang dibandingkan apabila data yang dicari $(X)$ lebih besar dari pada yang sedang dibandingkan sekarang.

3. Jika data terurut secara menurun (descending), maka pencarian hanya akan dilanjutkan ke data selanjutnya yang berada di sebelah kanan data yang sedang dibandingkan apabila data yang dicari $(X)$ lebih kecil daripada data yang sedang dibandingkan sekarang. Jika syarat-syarat di atas dipenuhi, maka pencarian data akan dilakukan sampai data yang dicari $(X)$ ditemukan sehingga pencarian dinyatakan sukses atau sampai elemen terakhir dari barisan A dan tidak ada elemen $A$ yang sama dengan data yang dicari $(X)$ sehingga pencarian dinyatakan gagal. Algoritma pencarian linier dapat dituliskan sebagai berikut Input : Barisan $A \ldots A[G]$ dan $X$. Output : Pesan $X$ ditemukan atau $X$ tidak ditemukan. Metode : Algoritma untuk data tidak terurut (data acak). Metode pencarian linier untuk data tidak terurut (data acak) dalam bahasa pemrograman Basic adalah sebagai berikut $\mathrm{I}=1$ : Ketemu $=$ False While $(\mathrm{I}<=\mathrm{N})$ And Not $($ Ketemu) If $(\mathrm{X}=\mathrm{A}(\mathrm{I}))$ Then Ketemu $=$ True Else $\mathrm{I}=\mathrm{I}+1$ End If Wend If (Ketemu) Then Print X, " ditemukan" Else Print X, " tidak ditemukan" Berdasarkan source code program metode pencarian linier di atas terlihat bahwa inti algoritma pencarian linier adalah bagian perulangan (loop) yaitu While dengan dua kondisi yakni $M<=N$ yang mengontrol agar perulangan jangan sampai melewati batas $N$ dan Not (ketemu) yang mengontrol pencarian apabila data sudah ditemukan maka pencarian tidak perlu lagi dilanjutkan. Jadi, hal yang mengakibatkan proses pencarian keluar dari bagian perulangan adalah barisan sudah habis yakni $M \Rightarrow$ $N$ atau data yang dicari sudah ditemukan yakni ketemu $=$ True. 
Dalam mengembangkan aplikasi ini, metodologi yang digunakan adalah model air terjun (waterfall). Dalam pengembangannya metode waterfall memiliki beberapa tahapan yang berurut yaitu : [10]. Analisis Syarat dan Ketentuan (Requirements definition), Mengumpulkan apa yang dibutuhkan secara lengkap untuk kemudian dianalisis guna mendefinisikan kebutuhan yang harus dipenuhi oleh program yang akan dibangun. Fase ini harus dikerjakan secara lengkap untuk bisa menghasilkan desain yang lengkap. [11]. Sistem dan Desain Perangkat Lunak (System and software design), Setelah apa yang dibutuhkan selesai dikumpulkan dan sudah lengkap maka desain kemudian dikerjakan. [12]. Implementasi dan Pengujian Unit (Implementation and unit testing), Desain program diterjemahkan ke dalam kode-kode dengan menggunakan bahasa pemrograman yang sudah ditentukan. Program yang dibangun langsung diuji secara unit, apakah sudah bekerja dengan baik. [13]. Integrasi dan Pengujian Sistem (Integration and system testing), Penyatuan unit-unit program untuk kemudian diuji secara keseluruhan (system testing). [14]. Operasi dan Pemeliharaan (Operation and maintenance), Mengoperasikan program di lingkungannya dan melakukan pemeliharaan, seperti penyesuaian atau perubahan untuk adaptasi dengan situasi yang sebenarnya.

\section{HASIL DAN PEMBAHASAN}

Sequential Search adalah teknik pencarian data secara urut dari depan ke belakang atau dari awal sampai akhir berdasarkan key yang dicari. Kelebihan proses pencarian secara sequential :

1. Jika data yang dicari terletak di depan, maka data akan ditemukan dengan cepat, tetapi dibalik kelebihannya ini memiliki kekurangan.

2. Jika data yang dicari terletak dibelakang atau paling akhir, maka akan membutuhkan waktu yang lama dalam pross pencariannya.

3. Beban komputer akan semakin bertambah jika jumlah data dalam array sangat banyak.

Proses:

1. Mulai dari awal (atau dari akhir) cek seluruh record dalam array atau list, baca satu-persatu.

2. Temukan record sesuai key yang dicari.

3. Proses Searching berhenti karena salah satu alasan,

a. Success - Found the target key

b. End of list - No more record to compare Diaplikasikan pada Array (sorted \& unsorted) Atau Linked List.[15]

Pada perkembangan teknik pemrograman berorientasi objek, munculah sebuah standarisasi bahasa pemodelan untuk pembangunan perangkat lunak yang dibangun dengan menggunakan teknik pemrograman yang berbasis objek yaitu Unifield Modeling Language (UML)". UML muncul karena adanya kebutuhan pemodelan visual untuk mengimplmentasikan, menggambarkan, membangun, dan dokumentasi dari sistem perangkat lunak. UML merupakan bahasa visual untuk pemodelan dan komunikasi mengenai sebuah sistem dengan menggunakan diagram dan teks-teks pendukung.
Semua hasil dan pembahasan penelitian ini diawali dari perancangan alur model sistem, hal ini dilakukan untuk memperjelas alur pengembangan software yang akan digunakan, berikut ini pengembangan alur dari UML (Unified Modelling Language) yaitu :

\section{A. Usecase Diagram}

Usecase merupakan sebuah teknik yang di pergunakan dalam pengembbangan sebuah software atau sistem informasi untuk memperoleh kebutuhan sistem yang akan di kembangkan

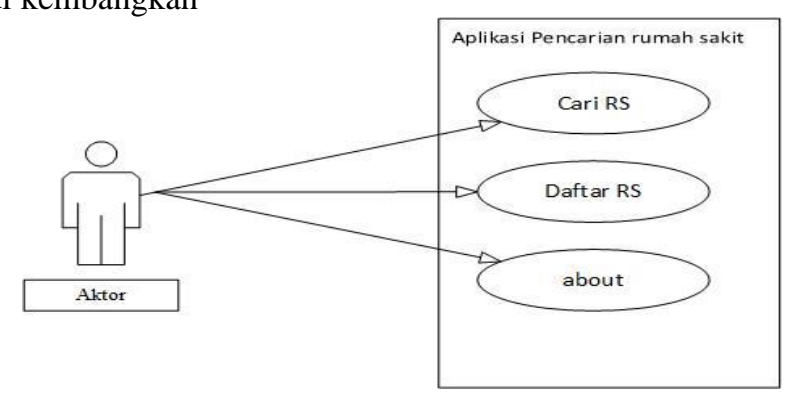

Gambar 1. Usecase Diagram aplikasi pencarian rumah sakit.

\section{B. Activity Diagram}

Activity adalah komponen android yang menyediakan tampilan didalam sebuah aplikasi di mana pengguna akan berinteraksi dengannya. Misal layar list chat pada aplikasi whatsapp android, user timeline yang ada di aplikasi twitter dan facebook anda, layar inbox pada aplikasi gmail anda dan lain sebagainya [16].

Activity Diagram merupakan bentuk visual dari alur kerja yang berisi aktivitas dan tindakan, yang juga dapat berisi pilihan, pengulangan, dan concurrency.

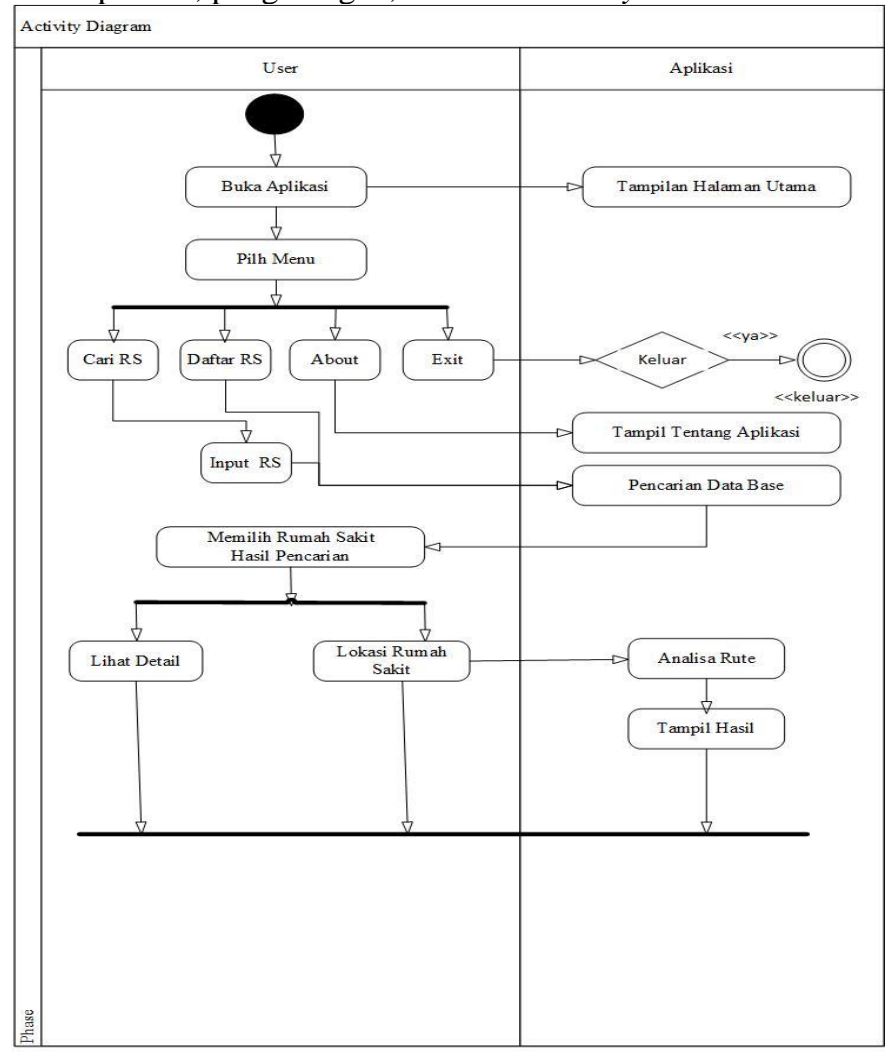

Gambar 2. Activity Diagram Aplikasi Pencarian Rumah Sakit 


\section{Implemetasi}

Pengembangan dari perancangan yang telah dibuat untuk diterjemahkan menjadi kumpulan kode dan fungsi menggunakan bahasa pemgograman tertentu sehinngga tercipta aplikasi yang telah direncanakan. Setelah tahap coding, maka tahap yang dilakukan selanjutnya adakah memasang sistem pada perangkat sebenernya, yaitu pada perangkat mobile android.

\section{Tampilan Splash Screen}

Tampilan splash screen merupakan tampilan utama di mana user pertama kali membuka aplikasi.

\section{囚EITAL \\ $\int$ Find hospital Easy}

Gambar 3. Tampilan splash screen

\section{Tampilan Menu Utama}

User bisa memiliki menu di aplikasi pencarian rumah sakit yaitu, cari RS, daftar RS, dan about.

FITAL - Find hospital
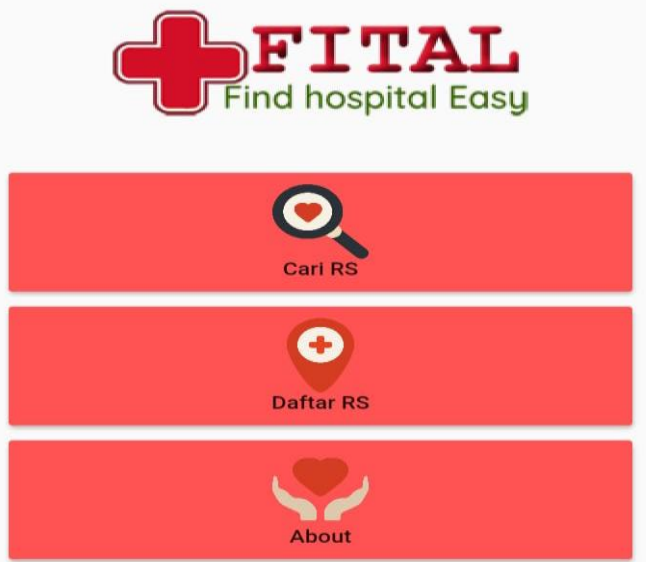

Gambar 4. Tampilan menu utama

\section{Tampilan Menu Cari RS}

Pada menu cari rs memili 2 menu yaitu pilih daerah dan input nama rumah sakit.

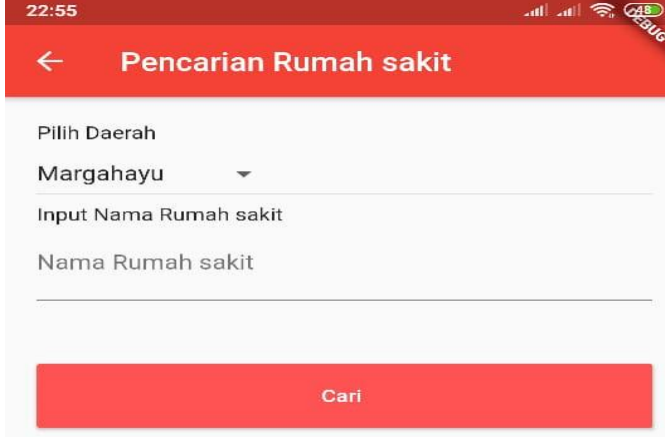

Gambar 5. Tampilan menu cari RS

\section{Tampilan Menu Daftar RS}

Pada menu ini berisikan nama nama rumah sakit di bekasi.

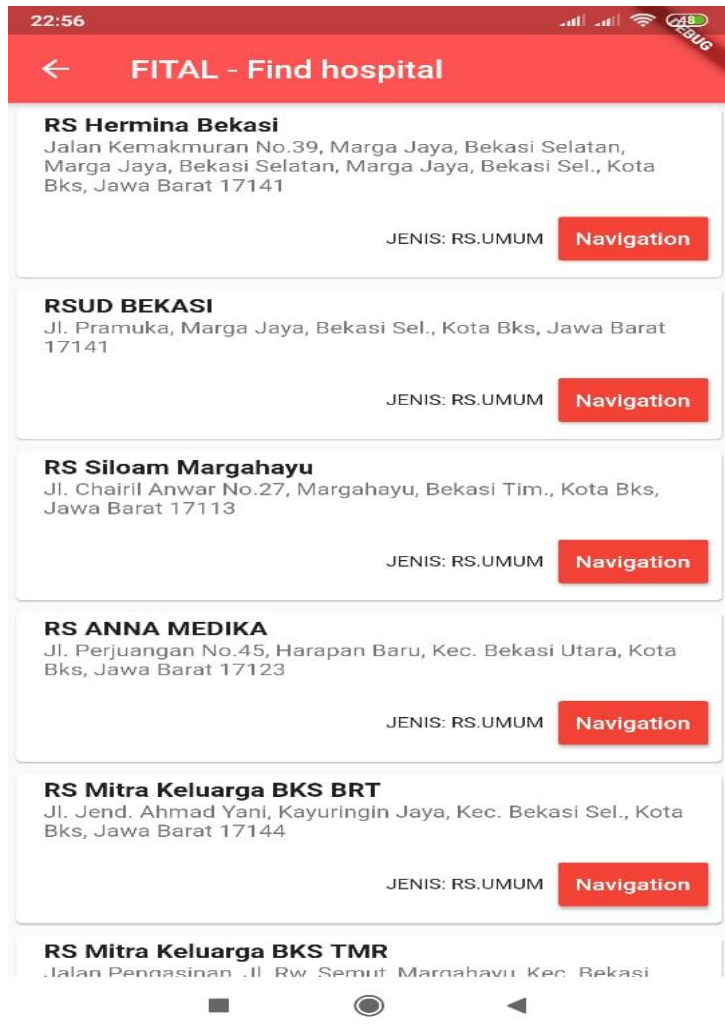

Gambar 6. Tampilan menu daftar RS

\section{About}

Pada menu ini terdapat keterangan siapa pembuat aplikasi ini dan fungsi pembuatan aplikasi pencarian rumah sakit terserbut. 


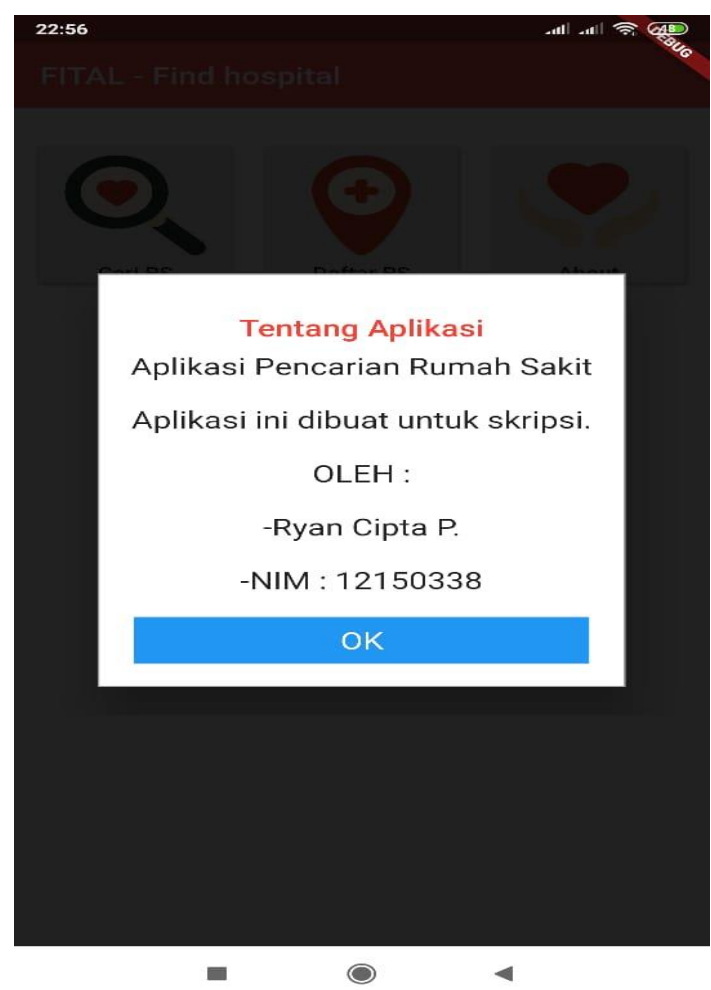

Gambar 7. Tampilan menu about

\section{KESIMPULAN}

Berdasarkan hasil implementasi aplikasi pencarian rumah sakit dan pembahasan pada bab-bab diatas maka kesimpulannya adalah:

1. Aplikasi yang sudah dibuat telah dapat memenuhi kebutuhan untuk melakukan proses pencarian rumah sakit dari piranti telpon cerdas dengan memberikan posisi yang cukup akurat.

2. Aplikasi pencarian rumah sakit ini dapat menampilkan rute perjalan ke rumah sakit dari dengan posisi pengguna berserta jaraknya sekarang ini dalam bentuk peta.

3. Hasil pengujian yang sudah dilakukan adalah bahwa fungsi-fungsi di aplikasi pencarian rumah sakit ini dapat berjalan dengan benar dan sesuai dengan krteria pembuatan.

\section{DAFTAR PUSTAKA}

[1] Purnomo, S., Subiyanto, S., \& Nugraha, A. (2017). ANALISIS POTENSI PERUNTUKAN LAHAN RUMAH SAKIT DINILAI DARI ASPEK FISIK DAN KEBUTUHAN PENDUDUK DENGAN SISTEM INFORMASI GEOGRAFIS DI KOTA SEMARANG. Jurnal Geodesi Undip, 6(4), 226-235.

[2] Rahmah, S., Sari, A. P., \& Nasution, R. (2018). Aplikasi SIG Mobile Finder Kampus BSI-Nusa Mandiri Jakarta Berbasis Android, 3-8.

[3] Adami, F. Z., \& Cahyani, B. (2016). Penerapan Teknologi Augmented Reality pada Media Pembelajaran Sistem Pencernaan Berbasis Android. Teknik Komputer AMIK BSI, 2(1), 122-131.

[4] Destiana. (2019). Pengaruh teknologi informasi berbasis android (Smartphone) dalam pendidikan industry 4.0. Prosiding Seminar Nasional Pendidikan Program Pascasarjana Universitas Pgri Palembang, 190-197.

[5] M. Rizal, "Perancangan Aplikasi Lokasi Wisata Kota Jakarta Menggunakan Algoritma Sequential Search Berbasis Android", pilar, vol. 13, no. 2, pp. 227-232, Mar. 2018.

[6] Mertha, I. M. P., Simadiputra, V., Setyawan, E., \& Suharjito, S. (2019). Implementasi WebGIS untuk Pemetaan Objek Wisata Kota Jakarta Barat dengan Metode Location Based Service menggunakan Google Maps API. InfoTekJar (Jurnal Nasional Informatika Dan Teknologi Jaringan), 4(1), 21-28. https://doi.org/10.30743/infotekjar.v4i1.1486

[7] Zarman, A., Irfan, M., \& Uriawan, W. (2016). Implementasi Algoritma Ant Colony Optimization pada Aplikasi Pencarian Lokasi Tempat Ibadah Terdekat di Kota Bandung. Jurnal Online Informatika, 1(1), 6 .

[8] Sonita, A., \& Sari, M. (2018). Implementasi Algoritma Sequential Searching Untuk Pencarian Nomor Surat Pada Sistem Arsip Elektronik. Pseudocode, 5(1), 1-9.

[9] Gunawan, G. (2016). Aplikasi Kamus Istilah Ekonomi (InggrisIndonesia) Menggunakan Metode Sequential Searching. Jurnal Pseudocode, 3(2).

[10] Abdulloh, R. (2017). Membuat Toko Online Dengan Teknik OOP MVC, dan AJAX. Jakarta: Elex Media Komputindo. Retrieved from

https://books.google.co.id/books?id=0C9IDwAAQBAJ\&printsec $=$ frontcover\&dq=mvc\&hl=id\&sa $=X \& v e d=0$ ahUKEwjnxJ3QtcrjA hUSXn0KHayqCoIQ6AEIKTAA\#v=onepage $\& \mathrm{q}=\mathrm{mvc} \& \mathrm{f}=$ false

[11] Adami, F. Z., \& Cahyani, B. (2016). Penerapan Teknologi Augmented Reality pada Media Pembelajaran Sistem Pencernaan Berbasis Android. Teknik Komputer AMIK BSI, 2(1), 122-131.

[12] Amin, R. (2017). Siswa Baru Pada Smk Budhi Warman 1 Jakarta. Jurnal Ilmu Pengetahuan Dan Teknologi Komputer, 2(2), 1-9.

[13] Ardy, J. D. \& M. R. (2018). Pengembangan aplikasi perencana wisata "plesir" berbasis android dan ios, (x), 1-11.

[14] Budihartanti, C., \& Pandiangan, R. (2016). Rancang Bangun Aplikasi Android Pencarian Rumah Sakit Di Jakarta Menggunakan Algoritma Dijkstra. Jurnal PROSISKO, 3(2), 1-8.

[15] Muhazir, A., Fakhriza, M., \& Sutejo, E. (2017). Implementasi Metode Sequential Dalam Pencarian Pendistribusian Barang pada Cargo Integration Sistem. Jurnal Dan Penelitian Teknik Informatika, 2(2), 24-30.

[16] Muslihudin, M., \& Oktafianto. (2016). Analisis Dan Perancangan Informasi Menggunakan Model Terstruktur Dan UML. (A. Pramesta, Ed.). Yogyakarta: CV Andi Offset. 